\title{
Complement in metabolic disease: metaflammation and a two-edged sword
}

\author{
B. C. King ${ }^{1} \cdot$ A. M. Blom ${ }^{1}$ (I)
}

Received: 12 April 2021 / Accepted: 23 May 2021 / Published online: 22 June 2021

(C) The Author(s) 2021

\begin{abstract}
We are currently experiencing an enduring global epidemic of obesity and diabetes. It is now understood that chronic low-grade tissue inflammation plays an important role in metabolic disease, brought upon by increased uptake of a so-called Western diet, and a more sedentary lifestyle. Many evolutionarily conserved links exist between metabolism and the immune system, and an imbalance in this system induced by chronic over-nutrition has been termed 'metaflammation'. The complement system is an important and evolutionarily ancient part of innate immunity, but recent work has revealed that complement not only is involved in the recognition of pathogens and induction of inflammation, but also plays important roles in cellular and tissue homeostasis. Complement can therefore contribute both positively and negatively to metabolic control, depending on the nature and anatomical site of its activity. This review will therefore focus on the interactions of complement with mechanisms and tissues relevant for metabolic control, obesity and diabetes.
\end{abstract}

Keywords Complement $\cdot$ Diabetes $\cdot$ Obesity $\cdot$ Inflammation $\cdot$ Adipocyte $\cdot$ Insulin $\cdot$ CD59 $\cdot$ C $3 \cdot C 4 B P$

\section{The complement system}

The complement system is an evolutionarily ancient mechanism of humoral innate immunity, composed of many serum proteins that activate in a sequential chain reaction, raising an immunological alarm upon pathogen detection (1). Activation products of complement are able to signal to and activate immune and endothelial cells, label pathogens for enhanced uptake and destruction by phagocytes and also kill some pathogens directly, by disruption of their surface membranes.

There are three canonical activation pathways of complement. For two of these pathways, soluble pathogen- or dangersensing molecules of complement (pattern recognition receptors, PRRs) can directly recognise pathogen- or dangerassociated molecular patterns (PAMPs, DAMPs) (Fig. 1A). The first of these two pathways is the lectin pathway, whereby

This article is a contribution to the Special issue on: Complement \& Disease: Out of the Shadow into the Spotlight - Guest Editors: Daniel Ricklin \& Richard B. Pouw

B. C. King

ben.king@med.lu.se

1 Department of Translational Medicine, Lund University, Lund, Sweden mannose-binding lectin (MBL), or one of several ficolins, bind to and recognise foreign or altered carbohydrate groups on pathogen surfaces or glycoproteins (3). The second is the classical pathway, so named because it was the first identified complement pathway, whereby the PRR C1q binds to antibody conformations arranged on surfaces of an antigenpositive target (4). Upon binding of these receptors, conformational changes occur and associated proteases become activated (MBL-associated serine proteases, MASPs, for the lectin pathway, or $\mathrm{C} 1 \mathrm{~s}$ and $\mathrm{C} 1 \mathrm{r}$ associated with $\mathrm{C} 1 \mathrm{q}$ in the classical pathway), cleaving the first components of complement activation, complement components 2 and $4(\mathrm{C} 2, \mathrm{C} 4)$. The resultant cleavage products, $\mathrm{C} 4 \mathrm{~b}$ and $\mathrm{C} 2 \mathrm{~b}$, together form an enzymatic complex covalently anchored to the activating surface, the $\mathrm{C} 3$ convertase, which cleaves complement component 3 (C3), which is the central or 'hub' component of the complement system.

C3 is a fascinating and multifunctional protein (5). When cleaved by its convertase, a peptide, $\mathrm{C} 3 \mathrm{a}$, is released, resulting in a large conformational change in the remaining protein, now called $\mathrm{C} 3 \mathrm{~b}$ (6). An 'arm' of $\mathrm{C} 3 \mathrm{~b}$ unfolds towards the activating surface, revealing a highly reactive thioester group within the thioester domain (TED), an unusual but highly conserved domain that functions in immune defence across the animal kingdom, from sponges (7) and corals (8), to 

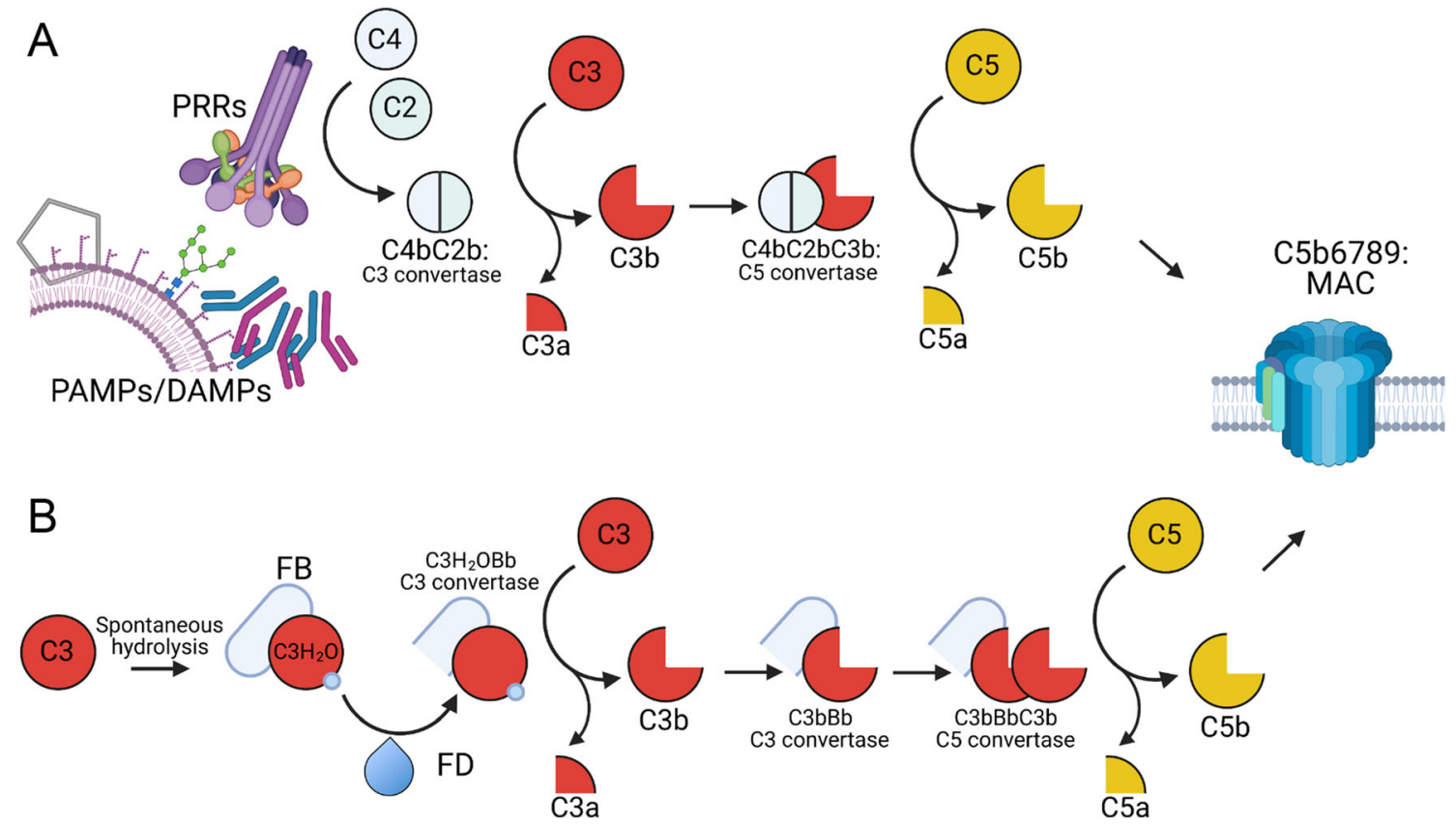

Fig. 1 Pathways of complement activation. A The classical and lectin pathways are activated by the PRRs, C1Q and MBL/ficolins respectively, which recognise PAMPs and DAMPS such as bound antibodies, dead cells and foreign or altered carbohydrates. PRRassociated proteases cleave $\mathrm{C} 2$ and $\mathrm{C} 4$, which form the $\mathrm{C} 3$ convertase, and subsequently cleave $\mathrm{C} 3$ into $\mathrm{C} 3 \mathrm{~b}$ and the anaphylatoxin $\mathrm{C} 3 \mathrm{a}$. $\mathrm{C} 3 \mathrm{~b}$ itself associates with $\mathrm{C} 4 \mathrm{bC} 2 \mathrm{~b}$ to form the $\mathrm{C} 5$ convertase, which cleaves $\mathrm{C} 5$ into the potent anaphylatoxin $\mathrm{C} 5 \mathrm{a}$, and $\mathrm{C} 5 \mathrm{~b}$. $\mathrm{C} 5 \mathrm{~b}$ then associates with complement components 6-9. Poly-C9 forms a membrane-breaching pore that can directly lyse gram-negative bacteria. B The alternative

insects and mammals. Once revealed, the thioester group reacts rapidly with adjacent hydroxy or amine groups, forming a covalent bond and irreversibly anchoring $\mathrm{C} 3 \mathrm{~b}$ to the surface via the thioester domain. In this way, the first function of complement is achieved, labelling pathogens with $\mathrm{C} 3$ activation products, which are themselves recognised by specific complement receptors on phagocytic cells, enhancing uptake and killing of pathogens.

Once $\mathrm{C} 3 \mathrm{~b}$ is deposited on activating surfaces, it can also interact with the $\mathrm{C} 3$ convertase, forming a larger complex with higher affinity for the next complement component, the serum protein $\mathrm{C} 5$. Cleavage of $\mathrm{C} 5$ also releases a peptide, C5a, and induces conformational change in the product, $\mathrm{C} 5 \mathrm{~b}$. C $5 \mathrm{~b}$ can bind to additional serum complement proteins $\mathrm{C} 6$ and $\mathrm{C} 7$, forming a complex, which then inserts into the plasma membrane of cells or gram-negative bacteria. This allows recruitment of serum complement component $\mathrm{C} 8$, and multiple copies of $\mathrm{C} 9$, which insert into the membrane and form a ring-like membrane-breaching pore, the membrane attach complex (MAC), capable of inducing rapid killing of target bacteria and cells, as membrane integrity is lost and cellular contents escape(9). This terminal activation pathway of complement represents a second canonical function of complement, direct killing of target cells.

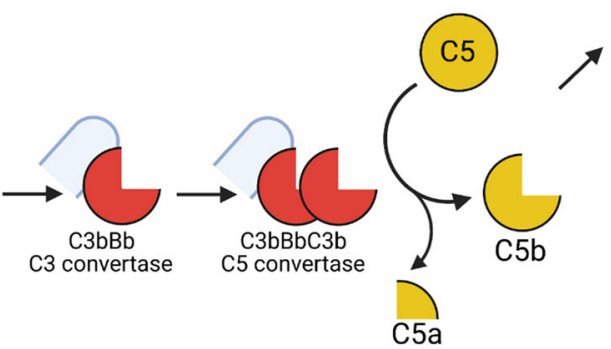

pathway is initiated by spontaneous hydrolysis of $\mathrm{C} 3$ to $\mathrm{C}_{3} \mathrm{H}_{2} \mathrm{O}$, to which FB can bind. Subsequent conformational changes allow serum protease $\mathrm{FD}$ cleave $\mathrm{FB}$ to $\mathrm{Bb}$, and $\mathrm{C}_{3} \mathrm{H}_{2} \mathrm{OBb}$ is the initial alternative pathway $\mathrm{C} 3$ convertase. $\mathrm{FB}$ also forms a convertase with subsequent $\mathrm{C} 3 \mathrm{~b}$ products, causing amplification unless regulated by $\mathrm{FH}$. Incorporation of $\mathrm{C} 3 \mathrm{~b}$ into the $\mathrm{C} 3$ convertase allows cleavage of $\mathrm{C} 5$, ultimately leading to MAC formation. The alternative pathway is also involved in amplification of the classical and lectin pathways. Previously, C2b was referred to as C2a (2). For further details, see text

The third important canonical function of complement is the production of the anaphylatoxins. Cleavage of $\mathrm{C} 4, \mathrm{C} 3$ and $\mathrm{C} 5$ all lead to release of peptides, $\mathrm{C} 4 \mathrm{a}, \mathrm{C} 3 \mathrm{a}$ and $\mathrm{C} 5 \mathrm{a}$, of which $\mathrm{C} 3 \mathrm{a}$ and $\mathrm{C} 5 \mathrm{a}$ are considered the most pro-inflammatory. These bind specific receptors on both immune and nonimmune cells, causing contraction of smooth muscle cells, vasodilation, degranulation of mast cells, cellular activation and chemotaxis of leukocytes to the site of complement activation, many of the signs of acute inflammation. Indeed, the symptoms of anaphylaxis are what give these peptides their group name of the anaphylatoxins. Complement is therefore a multifunctional system, capable of sensing danger via PRRs, and translating these danger signals into a whole range of appropriate acute responses, both activating and attracting effector cells, covalently labelling targets for uptake and clearance, and also causing direct destruction of some pathogens via MAC, acting on a timescale of minutes. Longer-term, complement activation also interacts with and acts as adjuvant to activation of the slower adaptive immune system, and generation of antigen-specific responses, a subject well-covered elsewhere (10).

As well as the classical and lectin pathways, a third pathway of complement activation exists, the alternative pathway (Fig. 1B). This was the last to be discovered but is the most 
evolutionarily ancient. While the classical pathway evolved relatively recently with the development of adaptive immunity, components of the alternative pathway evolved first, with both C3 and complement factor B (FB) having been identified in Oscarella carmella, a species of sponge (7), representing nearly the most evolutionarily ancient stage of multicellular animal life. The alternative pathway relies on the slow tick-over-activation that occurs by spontaneous hydrolysis of C3, whereby the thioester domain, although protected within the structure of intact $\mathrm{C} 3$, reacts with $\mathrm{H}_{2} \mathrm{O}$ to form $\mathrm{C}_{3} \mathrm{H}_{2} \mathrm{O}$, which then undergoes a conformational change similar to $\mathrm{C} 3 \mathrm{~b}$. Although the thioester group is neutralised and opsonisation cannot occur, $\mathrm{C}_{3} \mathrm{H}_{2} \mathrm{O}$ now binds serum protein FB, which is then cleaved by complement factor D (FD), also called adipsin. The complex of $\mathrm{C} 3 \mathrm{H}_{2} \mathrm{OBb}$ is now a soluble $\mathrm{C} 3$ convertase and can cleave further copies of $\mathrm{C} 3$ into $\mathrm{C} 3 \mathrm{~b}$. The spontaneous alternative pathwaymediated turnover of $\mathrm{C} 3$ is significant, at about $1 \%$ of $\mathrm{C} 3$ every hour (11), and is regulated by soluble complement inhibitors, the most important of which is factor $\mathrm{H}(\mathrm{FH})$. $\mathrm{FH}$ dissociates the convertase and causes inactivation of $\mathrm{C}_{3} \mathrm{H}_{2} \mathrm{O}$ by acting as a cofactor to serum protease factor I, which cleaves $\mathrm{C}_{3} \mathrm{H}_{2} \mathrm{O} / \mathrm{C} 3 \mathrm{~b}$. The activating potential of the alternative pathway can be seen in knockout mice lacking $\mathrm{FH}$; in these animals, the alternative pathway runs out of control, producing more and more copies of $\mathrm{C} 3$ convertase until the entire serum content of $\mathrm{C} 3$ is consumed, resulting in extremely low levels of serum $\mathrm{C} 3$, but high deposition of complement activation products, tissue damage and loss of function in vulnerable tissues, such as the kidneys (12) and eyes (13). Consequently, human FH polymorphisms that reduce its inhibitory activity are also associated with complement-mediated kidney and eye disease $(14,15)$.

The complement system is therefore both a signalling and effector mechanism involved in innate immune responses, but also has important roles in homeostasis and clearance of unwanted self-material, such as immune aggregates and apoptotic debris (16). Recent work has revealed that local complement activation and signalling can also function in other systems, particularly in neural development (17), and the proposal of autocrine functions of intracellular complement proteins has lead to speculation as to the very origin of complement, with potential evolutionary links to cellular metabolic pathways (18). This review will highlight the interactions between the complement system and major tissues involved in metabolic disease, with focus on the current epidemics of obesity and diabetes.

\section{Diabetes}

Diabetes is a major global human health burden, with hundreds of millions already currently affected worldwide, and with most rapid increases in incidence in developing countries. Diabetes is defined by a loss of control of blood glucose regulation, caused by an inability of insulin secretion to sufficiently meet the demand to clear blood glucose. As shall be described, this can be due to compromised levels of insulin secretion, a resistance of target tissues to respond to insulin, or a combination of both. An insufficiency of insulin relative to need leads to hyperglycaemia and resultant complications, including peripheral neuropathy, retinopathy and nephropathy.

Blood glucose homeostasis is reliant on the interplay of many different tissues, which must be understood in order to explain the pathogenesis of diabetes. In the healthy individual, breakdown of carbohydrates in food and subsequent absorption leads to an increase in blood glucose levels, which is quickly detected by $\beta$-cells found within the islets of Langerhans in the pancreas. Although making up only about $1 \%$ of the total pancreatic mass, the islets receive about 10 $20 \%$ of its total blood flow (19), being exceptionally wellvascularised. Expression of high-capacity glucose transporters leads to rapid uptake of glucose into $\beta$-cells, which is rapidly metabolised by mitochondrial oxidative phosphorylation, altering the intracellular ATP/ADP ratio. This leads to the opening of cell-surface ATP-sensitive potassium channels, causing membrane depolarisation and activation of voltage-gated calcium channels. This allows calcium entry into the cell, activating the calcium-dependent machinery of the exocytotic pathway, and ultimately leading to fusion of secretory granules with the cell surface, and release of insulin to the extracellular environment. Insulin acts on target tissues such as skeletal muscle and liver, triggering trafficking of intracellular pools of glucose transporters to the cell surface and rapid clearance of glucose from the blood for intracellular storage as glycogen. Insulin also has important effects on adipose tissue and lipid storage, decreasing rates of lipolysis and instead inducing triglyceride uptake (20). Diabetic patients with a relative lack of insulin production therefore often have increased plasma levels of both glucose and triglycerides.

Diabetes has historically been divided into two subsets, type 1 and type 2 . Type 1 diabetes (T1D) is an autoimmune disease typically defined by presence of autoantibodies against pancreatic islet antigens, involving an adaptive immune responsemediated destruction of pancreatic $\beta$-cells, destroying the source of insulin secretion. T1D typically has an early age of onset, and like many other autoimmune diseases, is linked to the HLA region of the genome, which defines which peptide antigens the adaptive immune system can recognise and therefore react against. The non-obese diabetic (NOD) mouse is a classic mouse model of T1D, which develop autoimmune Tcell-dependent diabetes at an early age. These mice were found to lack functional C5 (21), ruling out the involvement of the terminal pathways of complement in this model. Nevertheless, the presence of complement-fixing anti-islet antibodies has been demonstrated in sera from human T1D patients $(22$, 23), demonstrating a potential role of complement-mediated $\beta$-cell apoptosis and islet inflammation in the human disease. 
The development of autoimmune diabetes in a streptozotocininduced mouse model was also found to be dependent on expression of C3 within immune cells (24), most likely reflective of recent discoveries of autocrine functions of complement in immune cell activation and survival (25).

Type 2 diabetes (T2D), which makes up at least $90 \%$ of new diabetes diagnoses, has been linked to obesity, ageing and a so-called Western lifestyle, and is the most rapidly increasing form of the disease. T2D may develop due to a lack of insulin secretion, a loss of sensitivity of the target tissue to insulin signalling (known as insulin resistance), or a combination of both. This paradigm has been soundly validated by recent large-scale studies of thousands of human diabetes patients in various geographic locations (26-28), which have further stratified T2D into several subsets (29) (Table 1). These studies took into account measurements of $\beta$-cell function and insulin secretion, insulin sensitivity, BMI, age of onset, glycated haemoglobin and presence of autoantibodies, and identified 4 subtypes of T2D in addition to T1D. Of note, severe insulin-deficient diabetes (SIDD) and severe insulin resistance diabetes (SIRS) are two separately defined subtypes, with differing genetic associations $(26,29)$, showing that separate pathogenic mechanisms in different tissues may be responsible for producing different subsets of T2D.

\section{Evidence for complement involvement in diabetic complications}

Development of clinical diabetes and subsequent prolonged elevated blood glucose levels leads to not only known complications, including neuropathy, but also renal and retinal diseases. Indeed, deposition of complement activation products is a feature of both diabetes-related retinopathy (30) and nephropathy (31), although there is also evidence for lectin and classical pathway involvement; serum MBL levels are a strong biomarker for diabetic nephropathy in both T1D and T2D, and C4b as well as $\mathrm{Clq}$ were found deposited in human kidney samples from diabetic patients, correlating with nephropathy (32).
There is evidence that raised blood glucose levels can lead directly to dysregulation of complement inhibition, therefore leading to activation of complement and direct tissue pathology. Under prolonged exposure, plasma glucose can react with cell-surface molecules, chemically modifying them via a glycation reaction. Advanced glycation end products can directly activate complement via altered recognition by the carbohydrate-sensing PRR MBL (3), leading to complement deposition on endothelial surfaces. In addition, glycation can also inhibit protein function, for example in the case of CD59, a ubiquitously expressed inhibitor of MAC assembly. Under prolonged exposure to increased glucose, CD59 becomes glycated at its $\mathrm{C} 5 \mathrm{~b}-8$ binding site, therefore inactivating CD59 and allowing increased complement MAC formation at the cell surface (33). Due to the specificity of this glycation reaction and its requirement for prolonged elevated blood glucose levels, glycated CD59 has been assessed as a promising novel biomarker for gestational diabetes (34). Specific monoclonal antibodies detected glycated CD59 colocalising with $\mathrm{MAC}$ in kidneys and nerves from diabetic but not nondiabetic subjects (35), implicating glycation-mediated CD59 inactivation in complement-mediated diabetes-related nephropathy and neuropathy. Intense MAC staining has also been found in choriocapillaris of the eyes of diabetic retinopathy patients (30).

Diabetes is therefore associated with organ damage in eyes, kidneys and nerves, all tissues known to be sensitive to complement attack, as demonstrated by significantly increased risks of pathology at these sites in individuals harbouring polymorphisms or mutations in complement inhibitors (36), independent of diabetes. Deposition of activated complement proteins at these sites in diabetic patients, together with evidence for explanatory complement-activating mechanisms and CD59 inactivation, point to dysregulation of the complement system in diabetic complications. In support of this hypothesis, a recent study also found that a FH polymorphism significantly lowering plasma FH levels increased the risk for both renal dysfunction and cardiovascular events in a study of over 1100 human T2D patients (37).

Table 1 New definitions of clinical subtypes of diabetes, demonstrating heterogeneity of pathology (simplified from reference (26))

\begin{tabular}{lllllll}
\hline Subtype & $\%$ & Autoantibodies & $\begin{array}{l}\text { Insulin } \\
\text { secretion }\end{array}$ & $\begin{array}{l}\text { Insulin } \\
\text { resistance }\end{array}$ & BMI & Particular risks \\
\hline Severe autoimmune diabetes (SAID) & 6 & +++ & - & - & + & - \\
Severe insulin-deficient diabetes (SIDD) & 18 & - & - & + & + & Retinopathy, neuropathy \\
Severe insulin-resistant diabetes (SIRD) & 15 & - & ++ & ++ & ++ & Nephropathy fatty liver \\
Mild obesity-related diabetes (MOD) & 22 & - & + & + & + & + \\
Mild age-related diabetes (MARD) & 39 & - & + & + & Low risks \\
\hline
\end{tabular}

Importance of individual disease features were scored from -, (unimportant), to +++ (highly important) to show the relative incidence or importance of these features to the different subtypes of diabetes 


\section{The complement system in adipose tissue}

T2D is often associated with obesity, although as the recent T2D reclassifications show, it is possible to be overweight and metabolically healthy, as well as lean but diabetic. Obesity is associated with increased circulating markers of inflammation $(38,39)$, including the acute phase complement proteins such as C3 (40); circulating C3 levels were found to be predictive of future diabetes development in large patient cohorts (41, 42). Key studies in both obese people and mice also show that there are substantial changes in the populations of immune cells found in adipose tissue during obesity (43-46), with a skew towards pro-inflammatory phenotypes. Adipose tissue is not simply a passive site of lipid storage, but is an important endocrine tissue central to nutrient homeostasis (47), and a source of secreted adipokines that influence the brain, liver, muscle, gonads, vasculature and lymphoid organs (48). The normal function of adipose tissue is altered by obesity-induced inflammation, and low-grade tissue inflammation is now seen as an important factor in obesity-associated insulin resistance, leading to T2D development (49). There is therefore an interaction between adipose tissue and the innate immune system, which becomes altered in obesity, and which impacts upon metabolic function of adipocytes.

Adipose tissue is of central importance to the complement system, as FD, an essential component of the alternative pathway of complement activation, is produced primarily in adipocytes, where it was originally named adipsin before these two factors were discovered to be identical (50). FD cleaves FB into $\mathrm{Bb}$ and is therefore essential for activation of the alternative pathway of complement. Adiponectin-deficient mice completely lacking adipose tissue are also completely deficient in circulating FD, with minimal alternative pathway activity, demonstrating that adipose tissue is the primary source of circulating FD in rodents (51). FD is expressed as a zymogen, and the complement protein MASP-3 has been identified as the key factor that processes pro-FD into its active form (52). The MASP-3 protein is an alternative splice product from the MASP1 gene, and MASP1/3 knockout mice therefore have no functional FD, and subsequently a defective alternative pathway (53). These mice were also reported to weigh less than littermate controls, and had adipocytes of smaller size, suggesting defects in adipocyte development or lipid storage (54), demonstrating functional links between adipose tissue and the alternative pathway of complement activation.

This link has been attributed by one research group to inactivated $\mathrm{C} 3 \mathrm{a}$; once cleaved from $\mathrm{C} 3$ during complement activation, $\mathrm{C} 3 \mathrm{a}$ can be rapidly inactivated by removal of a single $\mathrm{C}$-terminal arginine residue, forming $\mathrm{C} 3 \mathrm{a}$-desArg. Baldo et al. identified that C3a-desArg stimulated lipogenesis in adipocytes (55), the synthesis of triglycerides for storage, and the same group also found that aged female C3-knockout mice, which therefore also lack $\mathrm{C} 3 \mathrm{a}$, were resistant to increases in body weight on a high-fat diet, and had lower blood levels of glucose and insulin (56), signifying improved metabolic homeostasis. In addition, these $\mathrm{C} 3-\mathrm{KO}$ mice, similar to MASP1/3 KO mice (54), had lower circulating levels of the appetite-regulating hormone leptin, which is also secreted from adipocytes. These results have however proven controversial, partly because of the fact that the interaction of C3aDesArg with the proposed receptor, C5L2 (57), has been disproven by other groups $(58,59)$. In addition, reproduction studies failed to confirm any changes in serum levels of free fatty acids, cholesterol or triglycerides between $\mathrm{C} 3-\mathrm{KO}$ or WT mice (60), although this was proposed to be due to differences in mouse genetic background (61), something that can dramatically affect mouse nutrient homeostasis and metabolism (62). The use of total C3-KO mice in these studies to specifically study the role of C3a-DesArg in adipocytes is also far from optimal, given the many other known and potential roles of $\mathrm{C} 3$ in other tissue types. However, pharmacological blockade of the complement anaphylatoxin receptors $\mathrm{C} 3 \mathrm{aR}$ and $\mathrm{C} 5 \mathrm{aR}$ in rats was shown to reverse high-fat diet-induced visceral adiposity and both glucose and insulin intolerance (63).

In addition to FD, adipocytes also express and secrete $\mathrm{C} 3$ and $\mathrm{FB}$, all the necessary components for alternative pathway activation. These are upregulated in adipocytes from both mice and human donors during differentiation (64) and after stimulation with pro-inflammatory cytokines (65), during which the alternative pathway becomes activated, with production of cleaved activation products of both FB and $\mathrm{C} 3$, showing that an autocrine alternative pathway can be activated by adipocytes, potentially forming a pro-inflammatory feedback loop (66). In fact, it has been shown that activation of complement, and production of anaphylatoxins, in particular, is responsible for induction of adipose tissue inflammation under high-fat diet feeding (63) and recruitment of proinflammatory macrophages into adipose tissue in diabetic mouse models $(65,67)$. In a recent extensive meta-analysis of genome-wide association studies analysing millions of single nucleotide variants in over 150,000 individuals, regulatory enhancer analysis revealed that genetic loci associated with insulin resistance showed tissue-specific enrichment for macrophages, strongly implicating this cell type in insulin resistance (68). The production of pro-inflammatory cytokines by these macrophages actually induces insulin resistance in adipocytes, rendering them less sensitive to insulin signalling (69), which leads to impaired blood glucose clearance, and compensatory increases in $\beta$-cell insulin expression, which contributes to ER stress and $\beta$-cell exhaustion. Evidence therefore points to local adipose tissue complement factor expression and activation contributing to adipose inflammation, recruitment of pro-inflammatory cells and subsequent induction of insulin resistance.

Serum samples from human lipodystrophy patients show a linear relationship between adipose mass and circulating FD 
levels. Accordingly, levels of FD in human patients correlate with both BMI and waist circumference (70), consistent with adipose tissue being the main known source of serum FD. As obesity is a clear risk factor for development of T2D and is linked to inflammation, and inflammatory cytokines stimulate increased adipocyte FD expression, it may therefore be expected that an increase in adiposity, and therefore an increase in FD, would correlate with diabetes development. However, the picture is more complex than this; not all adipose tissue is equal. Circulating FD does not originate equally from adipose tissue at different anatomical sites; high expression of FD is linked to subcutaneous, but not visceral fat (70), and visceral fat specifically, is a risk factor for T2D development, while subcutaneous fat may even be protective (71); transplanting subcutaneous fat into the visceral compartment can even lead to reduced overall adiposity and improved glucose homeostasis (72). While overall increased BMI is a risk factor for T2D development, increased FD levels are correlated with decreased T2D incidence, and improved fasting blood glucose levels (70). In fact, diabetic and obese individuals, and even obese rodent models of T2D, have significantly lower serum levels of FD (50, 73-75), while mRNA levels of FD are increased in normal rats during fasting (73). While FD is therefore derived primarily from adipocytes, there are therefore clear differences in the function of adipose tissue at different anatomical sites, with differing associations between anatomical site, FD production, and contribution to T2D development. It should also be noted that circulating FD levels relate to renal function, as at only $24 \mathrm{kDa}, \mathrm{FD}$ is cleared from the blood by glomerular filtration (76), which is initially increased in hyperglycaemia, but can be affected by diabetes-associated kidney disease.

Evidence of the differing complement activity of adipose tissue at anatomical different sites can also be found in cases of acquired partial lipodystrophy (APL). APL is a disorder that leads to loss of adipose tissue from specific anatomical sites, typically from the upper body (the face, arms and abdomen), but not from the buttocks or legs, leading to a wildly skewed fat distribution. Loss of adipose storage depots leads instead to ectopic lipid deposition in muscle and liver, leading to fatty liver disease and liver failure. Increased circulating triglyceride levels also contribute to insulin resistance of other tissues. APL is currently thought to be largely complementmediated, with $83 \%$ of patients in one study testing positive for nephritic factor, an autoantibody that stabilises the alternative pathway $\mathrm{C} 3$ convertase $\mathrm{C} 3 \mathrm{bBb}$, leading to complement over-activation and consumption (77), which presents as very low patient serum C3 levels. APL patients were also at a highly increased risk of developing a complement-mediated kidney disease (78), membranoproliferative glomerulonephritis (MPGN). The question therefore arises as to why only certain anatomical sites in these patients are vulnerable to loss of adipocytes in the presence of nephritic factor. Adipocytes themselves express all the necessary components for alternative pathway activation, and so it could be speculated that nephritic factor stabilises this convertase at the site where it is most efficiently produced, leading to over-activation of complement and inducing death of adipocytes at those sites. This hypothesis is supported by in vitro induction of adipocyte apoptosis by nephritic factor (79). This would therefore indicate that adipocytes at the sites most vulnerable to nephritic factor are also those producing highest amounts of the alternative pathway components, particularly FD, therefore suggesting that adipose tissue in the upper body likely expresses higher amounts of FD. Inflammation induced by nephritic factor could also induce further expression of complement components by adipocytes at these sites (66), leading to positive feedback of complement activation and expression, and resultant pathology.

\section{The control centre: functions of complement in pancreatic islets}

The main function of pancreatic islets is the regulation of blood glucose levels by secretion of $\beta$-cell-derived insulin, and $\alpha$-cell-derived glucagon. The pancreatic islet is therefore the control centre of blood glucose regulation. Diabetes is caused by a relative deficiency of insulin compared to need (80), which can be caused by loss of $\beta$-cell and insulin secretion capacity, or decreased effectiveness of insulin due to development of insulin resistance in target tissues, or a combination of the two. While immune infiltration of the pancreatic islet, autoimmune attack and $\beta$-cell loss are the hallmarks of T1D, infiltration of pro-inflammatory cells and associated loss of function also occurs in T2D islet (81), as also witnessed in rodent models of diet-induced diabetes (82). While the proinflammatory potential of the complement system is well understood, investigations into the role of complement in the pancreatic islet have led to surprising findings as to non-canonical, homeostatic and protective functions of individual complement proteins.

\section{C3/C3a}

As described above, cellular metabolism of $\beta$-cells, and the subsequent intracellular ATP/ADP ratio, directly influences insulin secretion. In recent years, it has been discovered that the activation of complement can act as a switch for cellular metabolism. Once activated, $\mathrm{C} 3 \mathrm{~b}$ acts as a ligand for the complement inhibitor and cell-surface receptor CD46, and CD46 ligation leads to potent activation of human $\mathrm{CD}^{+}{ }^{+}$-cells (83). T-cell activation and subsequent differentiation involve induction of rapid proliferation and upregulation of metabolism, and this was found to be dependent on CD46 signalling (84, 
85). Complement activation products can therefore have direct effects on cellular metabolism on shorter timescales. Similarly, the $\mathrm{C} 3$ activation product, $\mathrm{C} 3 \mathrm{a}$, has been shown to stimulate $\beta$-cell metabolism, causing increases in oxidative phosphorylation (75). Consequently, the resultant increase in $\mathrm{ATP} / \mathrm{ADP}$ ratio also meant that $\mathrm{C} 3 \mathrm{a}$ augments insulin secretion. $\mathrm{C} 3 \mathrm{a}$ can be produced by the alternative pathway convertase, formed when $\mathrm{FB}$ binds to $\mathrm{C} 3 \mathrm{~b} /$ hydrolysed $\mathrm{C}_{3} \mathrm{H}_{2} \mathrm{O}$, and is cleaved by FD. Although FD/adipsin is decreased in sera of obese/diabetic humans and rodents, replenishing serum FD levels by viral re-introduction into obese diabetic ob/ob mice (75) rescued blood glucose homeostasis. This was attributed to the recovery of the alternative pathway function, and production of $\mathrm{C} 3 \mathrm{a}$, which presumably acts on $\beta$-cell. In a follow-up paper, it was also shown that C3a blocked $\beta$-cell de-differentiation and inhibited apoptosis, via regulation of phosphatase DUSP6 (70). These results together suggest a profound effect of the alternative pathway and $\mathrm{C} 3 \mathrm{a}$ in particular on $\beta$-cell identity, function and survival. The fact that adipocytes are the main source of FD means that the complement system is a means of communication between adipose tissue and pancreatic islets, and regulation of expression of these factors at these different sites is therefore of direct relevance to metabolic control.

C3 is highly expressed in isolated human pancreatic islets (86), and expression analysis revealed that C3 expression is significantly upregulated in islets from T2D patients compared to healthy donors, and is upregulated in islets in multiple rodent models of diabetes (87). C3 secretion from isolated human islets is augmented by IL- $1 \beta$ exposure, and C 3 expression in freshly isolated islets correlated with expression of proinflammatory cytokines, as well as with donor body mass index, and HbA1c, linking islet $\mathrm{C} 3$ expression with islet inflammation, obesity and diabetes. Surprisingly, protein interaction microarrays and ELISA confirmation revealed an interaction with isoforms of ATG16L1, a protein central to autophagy, and consequently, CRISPR/Cas9-mediated knockout of the $\mathrm{C} 3$ gene in $\beta$-cell INS-1 832/13 clones led to dysfunctional autophagy, whereby autophagosomes were unable to mature, and accumulated within the cell. The failure of autophagy in these cells led to increased apoptosis under exposure to stress-inducing diabetogenic factors, such as exposure to glucolipotoxic conditions, or IAPP (87). Isolated islets from C3 knockout mice also displayed a dysfunctional autophagic phenotype. These findings strongly implicate a non-canonical role for $\mathrm{C} 3$ in regulating autophagy within $\beta$-cells.

ATG16L1 is found within the cytosol, whereas C3 is canonically found in the secretory pathway and extracellular environment. The interaction of C3 with ATG16L1 has been demonstrated within the cytosol in the context of pathogen invasion, whereby $\mathrm{C} 3$-opsonised bacteria entering the cytosol are detected by ATG16L1 and targeted by autophagy (88). However, results indicating that a direct interaction between
C3 and ATG16L1 regulates homeostatic autophagy pose a challenge regarding the subcellular localisation of these proteins. A solution was found by identification of in-frame alternative start codons found within $\mathrm{C} 3$ cDNA, directly downstream of the signal peptide. Use of these codons would result in C3 protein expressed directly into the cytosol. This was confirmed by mutation of the canonical ATG start site, whereby significant levels of $\mathrm{C} 3$ were expressed within the cytosol of cells, with no C3 secretion (87). Although activation products of canonical complement activation pathways have been shown to regulate autophagy via ligation of cell-surface receptors (89), the interaction of C3 directly with ATG16L1 represents a new mode in which intracellular, cytosolic isoforms of C3 promote pro-survival homeostatic cellular processes (90).

Islet-expressed $\mathrm{C} 3$ has also been shown to be a pro-survival factor during inflammation, with siRNA-mediated C3 knockdown leading to increased apoptosis in dispersed islet cells exposed to pro-inflammatory cytokines (91). Here, unlike for autophagy dysfunction, exogenously added C3 partially rescued the effect of $\mathrm{C} 3$ knockdown, and $\mathrm{C} 3 \mathrm{aR}$ was implicated in mediating the effect. In lung epithelial cells, intracellular stores of C3 have also been shown to mediate cytoprotection against oxidative stress (92), and 'stores' of intracellular C3 have also been implicated in $\mathrm{CD}^{+} \mathrm{T}$-cell survival (25). $\mathrm{C} 3$, and possibly $\mathrm{C} 3 \mathrm{a}$, may therefore have several roles within the islet, regulating autophagy, insulin secretion and $\beta$-cell identity, but also promoting cellular survival during stress and inflammation. The comparative contributions of exogenous or secreted C3 compared to intracellular C3 remains to be investigated, as well as the balance between these novel protective effects of $\mathrm{C} 3$, compared to potential deleterious outcomes of canonical pro-inflammatory extracellular complement activation within the islet.

\section{CD59}

As described above, the terminal pathway of complement activation leads to production of the pore-forming MAC, which deposits into membranes. In order for host cells to protect themselves from MAC-dependent membrane damage, all human cells express CD59, a small protein that is anchored to the cell surface by a glycosylphosphatidylinositol (GPI) anchor. The GPI anchor consists of glycolipid post-translational modification that is added to the nascent protein within the endoplasmic reticulum, before transport to the cell surface. CD59 is able to intercept $\mathrm{C} 5 \mathrm{~b} 67$ after it inserts into the cell membrane, but before $\mathrm{C} 9$ is recruited to form the membrane-breaching pore. By blocking C9 integration, CD59 therefore prevents MAC formation and subsequent cell damage. The importance of this is seen in patients that experience somatic mutations in haematopoeitic stem cells, in the PIG-A gene, which encodes an enzyme required for GPI anchor synthesis. The resultant 
CD59-deficient red blood cells are susceptible to complement-mediated lysis, a disease known as paroxysmal nocturnal haemoglobinuria (93).

During investigation of how complement proteins may contribute to $\beta$-cell function, we knocked down CD59 in $\beta$-cell clones using siRNA, and discovered that cells lacking CD59 expression were unable to secrete insulin in response to glucose (86). Knockdown cells were also unresponsive to high potassium, which 'short-circuits' insulin secretion signalling by causing membrane potential depolarisation, suggesting that CD59 functions towards the distal end of the insulin secretion pathway. Proximity ligation assays also showed a co-localisation of CD59 with syntaxin and VAMP2, proteins located to the cytosolic facing membranes of the cell surface and insulin granules respectively, again suggesting that CD59 is involved in the mechanics of insulin granule fusion with the cell surface. Furthermore, in contrast to results with siRNA, enzymemediated removal of CD59 from the cell surface by cleavage of GP anchors did not affect insulin secretion, suggesting that the pool of CD59 involved in GSIS resides within the cell. These results therefore revealed a non-canonical function of intracellular CD59 in insulin secretion, separate from its canonical cell-surface role in inhibition of MAC deposition.

This work was followed up by a study in which CD59 was knocked down using siRNA, and then replaced by transfection with synonymously coded cDNA constructs that escaped siRNA-mediated targeting but contained various targeted mutations. The main finding from this study concerned the GPI anchor; a version of CD59 lacking the C-terminal GPI signal peptide and attachment site rescued insulin secretion in cells lacking endogenous CD59, showing that non-GPI-anchored CD59 isoforms were involved in insulin secretion (94). When un-anchored, CD59 within the secretory pathway was retrotranslocated into the cytosol, a process dependent on recognition of the trimmed N-linked glycosylation site, and once within the cytosol this form of CD59 interacted with insulin secretion machinery. This was confirmed in $\beta$-cell clones where PIG-A was knocked out using CRISPR/Cas9: these cells did not express cell-surface CD59 but were still able to secrete insulin in response to glucose, unless CD59 expression was knocked down using siRNA, showing that secretion was reliant on non-GPI-anchored CD59 (94).

While the mechanisms of the function of CD59 in insulin granule exocytosis are still being investigated, the interactions are mediated via the specific protein domain of CD59, as removal of CD55, a similar GPI-anchored complement regulator, had no effect on insulin secretion (95), and overexpression of Thy1, another cell-surface GPI-linked protein, did not rescue insulin secretion in CD59-deficient cells (86). While results from cell lines are clear-cut, the physiological relevance is still to be confirmed. While multiple rodent models of diabetes displayed altered islet expression of CD59 (86), we have not seen significant changes in overall CD59 transcripts in human samples. CD59 is however highly expressed and abundant at the cell surface, in keeping with its important role in cellular defence against complement, and if only a small subset of total CD59 is targeted to the cytosolic environment, then even significant changes in this subpopulation may not translate to noticeable changes in total CD59 transcript levels. In addition, there are no reports of diabetic phenotypes in CD59 knockout animals, although this may not have yet been studied directly. There may be compensatory mechanisms in play in mice, which have two copies of the CD59 gene with differing tissue expression patterns (96). It is interesting to note that the CD59 gene identified in guinea pigs lacks a functional domain for GPI anchorage and was not expressed at RNA levels in tested tissues (the brain, liver, lung, muscle, kidney and cervix) (97), and therefore may also have limited tissue expression and function in regulated secretion in an intracellular manner.

As for human cases, rare patients exist with germlineinherited mutations in CD59, and therefore lack functional cell-surface CD59 in all cells. These patients not only experience haemolysis, but also develop progressive childhood demyelinating neuropathy (36) that can be fully treated by clinically available complement inhibitors. So far, insulin secretion deficiencies have not been described in these patients, but CD59 cDNA containing one of the reported mutations, C89Y, did rescue insulin secretion, despite this mutant not reaching the cell surface, and it would therefore appear that the intracellular and cell-surface functions of CD59 have separate structural requirements.

\section{C4BP}

Islet amyloid polypeptide, IAPP, is a hormone peptide that is cosecreted with insulin from $\beta$-cells. IAPP also forms amyloid deposits in the pancreas, with increased amyloid deposition in diabetes, correlating with $\beta$-cell loss (98). We discovered previously that complement, which is known to be involved in clearance of dead cells and protein aggregates, also interacts with amyloid deposits $(99,100)$. In particular, complement inhibitor $\mathrm{C} 4 \mathrm{~b}$-binding protein $(\mathrm{C} 4 \mathrm{BP})$ has a role in regulating complement activation so that IAPP deposits are detected and cleared, without causing excessive complement-mediated inflammation (100). IAPP can however be directly cytotoxic, as its oligomers/ multimers interact with and disrupt cell membranes (101). We also showed that C4BP binds to IAPP oligomers, and blocks their cytotoxic activity, protecting $\beta$-cells (102). IAPP oligomers can also activate the inflammasome, becoming internalised by myeloid cells and disrupting lysosomal integrity (103), leading to NLRP3 activation and release of the pro-inflammatory cytokine IL- $1 \beta$, which contributes to islet inflammation and $\beta$-cell dysfunction (104). C4BP, which is expressed in delta-cells of the pancreatic islet, also inhibited IAPP-dependent inflammasome 
activation, with a resultant rescue of $\beta$-cell function and insulin secretion (105). C4BP therefore acts as both an inhibitor of complement-dependent activation, but also has a non-canonical role as an inhibitor of IAPP-mediated cytotoxicity and inflammation independent of its complement-regulatory function, therefore acting at several levels to protect homeostasis and function of the pancreatic islet (106).

\section{Conclusions}

It is intriguing to note that as well as the evidence for the involvement of complement in influencing cellular metabolism in mammals, it has recently been shown that even insects lacking C3-related thioester-containing proteins have altered carbohydrate and triglyceride levels (107), suggesting an evolutionarily ancient link between complement and metabolism (18). Diabetes is a complex disease, involving interactions of many tissues and cell types at different anatomical sites within the body. Apart from the classification into T1D and T2D, it is now apparent that T2D can be subdivided into further subtypes, defined by different clinical features and with differing genetic associations. The heterogenous nature of the disease may have previously obscured roles of distinct inflammatory pathways, which may play different roles in distinct diabetes subtypes. The identification of these novel subtypes is therefore a first step towards a 'personalised medicine' approach, where specific pathways can be targeted in specific patients.

Similarly, the complement system has a complex role in the disease, playing opposing beneficial and detrimental roles in different tissues (Fig. 2). Inflammation plays a direct role in inducing both insulin resistance and $\beta$-cell dysfunction, and there is a clear role for the canonical functions of complement in recruiting pro-inflammatory leukocytes to adipose tissue, as well as in causing direct pathology in the clinical complications of chronic diabetes. However, there is increasing evidence for beneficial local roles of complement in tissue homeostasis of both adipose tissue and pancreatic islets, in particular for roles of both the alternative pathway, and $\mathrm{C} 3 \mathrm{a}$, as well as for intracellular complement, in the case of intracellular isoforms of both CD59 and C3. With FD being primarily produced in adipose tissue, and $\mathrm{C} 3$ a seeming to act on islets to improve function and survival, the alternative pathway of complement also seems to present a novel means of communication between these different tissues, although how this may be targeted specifically to $\beta$-cells has not been investigated. The nature of complement as a 'two-edged sword', capable of both negatively and positively influencing whole-body metabolism by differing activity in different tissues, calls for further work to understand the details of these relative contributions. In particular, novel tissue-specific knockout mice are required to understand relative contributions of circulating and locally produced complement factors, as well as relative roles of intra- and extracellular proteins. Inflammatory pathways are now being carefully considered as therapeutic targets in diabetes and metabolic disease (108), and inhibitors of complement are finding their way towards the clinic (109). Better understanding of the mechanisms and outcomes of complement pathways, and their interplay with metabolism, will path the way to improved personal medicine and tailored treatments of metabolic disturbances.
Fig. 2 Interactions of complement with metabolic tissues. Serum complement proteins are derived mainly from the liver with the exception of FD, which is expressed primarily in adipocytes and is altered in obesity. Local C3 expression is also found at various anatomical sites. In particular, C3 is highly expressed in human islets. Both circulating levels of $\mathrm{C} 3$ and local islet $\mathrm{C} 3$ expression are upregulated during T2D. Notably, $\mathrm{C} 3 \mathrm{a}$ has been shown to have direct effects on both adipocytes and $\beta$-cells, while intracellular isoforms of both C3 and CD59 play homeostatic roles in $\beta$-cell survival and function

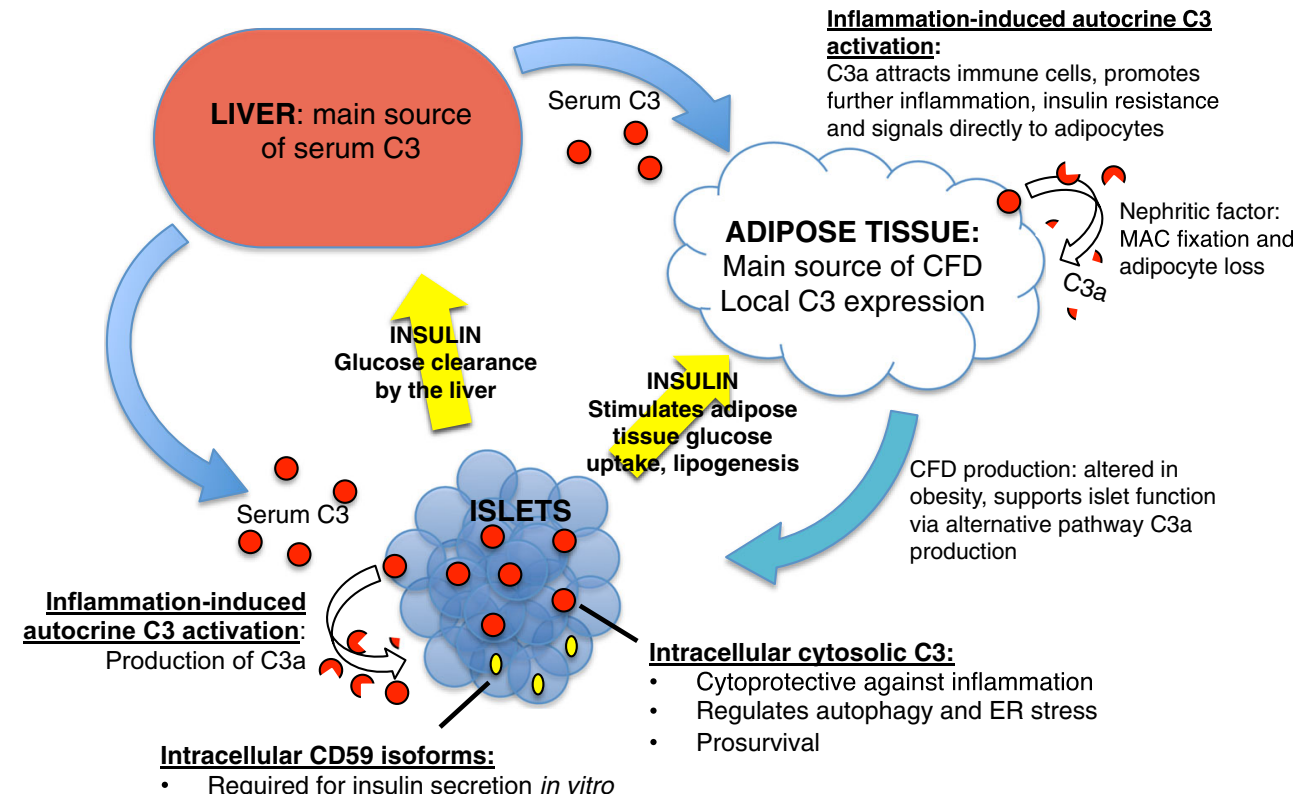


Acknowledgements This work was supported by grants from the Knut and Alice Wallenberg Foundation, the Novo Nordisk Foundation, the Swedish Foundation for Strategic Research Dnr IRC15-0067, Swedish Research Council Dnr 2018-02392 and Strategic Research Area Exodiab, Dnr 2009-1039, The Diabetes Foundation, the Crafoord Foundation, Åke Wiberg Foundation, Albert Påhlsson Foundation and the Magnus Bergvall Foundation. Figure 2 was created with BioRender.com.

Funding Open access funding provided by Lund University.

\section{Declarations}

Conflict of interest The authors declare no competing interests.

Open Access This article is licensed under a Creative Commons Attribution 4.0 International License, which permits use, sharing, adaptation, distribution and reproduction in any medium or format, as long as you give appropriate credit to the original author(s) and the source, provide a link to the Creative Commons licence, and indicate if changes were made. The images or other third party material in this article are included in the article's Creative Commons licence, unless indicated otherwise in a credit line to the material. If material is not included in the article's Creative Commons licence and your intended use is not permitted by statutory regulation or exceeds the permitted use, you will need to obtain permission directly from the copyright holder. To view a copy of this licence, visit http://creativecommons.org/licenses/by/4.0/.

\section{References}

1. Kohl J (2006) The role of complement in danger sensing and transmission. Immunol Res 34:157-176

2. Bohlson SS, Garred P, Kemper C, Tenner AJ (2019) Complement nomenclature-deconvoluted. Front Immunol 10:1308

3. Hevey R, Pouw RB, Harris C, Ricklin D (2020) Sweet turning bitter: carbohydrate sensing of complement in host defence and disease. Br J Pharmacol

4. Ugurlar D, Howes SC, de Kreuk BJ, Koning RI, de Jong RN, Beurskens FJ, Schuurman J, Koster AJ, Sharp TH, Parren P, Gros P (2018) Structures of C1-IgG1 provide insights into how danger pattern recognition activates complement. Science 359: 794-797

5. Ricklin D, Reis ES, Mastellos DC, Gros P, Lambris JD (2016) Complement component C3 - the "Swiss Army Knife" of innate immunity and host defense. Immunol Rev 274:33-58

6. Wang J, Takeuchi T, Tanaka S, Kubo SK, Kayo T, Lu D, Takata K, Koizumi A, Izumi T (1999) A mutation in the insulin 2 gene induces diabetes with severe pancreatic beta-cell dysfunction in the Mody mouse. J Clin Invest 103:27-37

7. Poole AZ, Kitchen SA, Weis VM (2016) The role of complement in cnidarian-dinoflagellate symbiosis and immune challenge in the sea anemone Aiptasia pallida. Front Microbiol 7:519

8. Nonaka M (2011) The complement $\mathrm{C} 3$ protein family in invertebrates. Invertebr Surviv J 8:21-32

9. Sharp TH, Koster AJ, Gros P (2016) Heterogeneous MAC initiator and pore structures in a lipid bilayer by phase-plate cryo-electron tomography. Cell Rep 15:1-8

10. Carroll MC (2004) The complement system in regulation of adaptive immunity. Nat Immunol 5:981-986

11. Pangburn MK, Schreiber RD, Muller-Eberhard HJ (1981) Formation of the initial C3 convertase of the alternative complement pathway. Acquisition of C3b-like activities by spontaneous hydrolysis of the putative thioester in native C3. J Exp Med 154: 856-867

12. Pickering MC, Cook HT, Warren J, Bygrave AE, Moss J, Walport MJ, Botto M (2002) Uncontrolled C3 activation causes membranoproliferative glomerulonephritis in mice deficient in complement factor $\mathrm{H}$. Nat Genet 31:424-428

13. Coffey PJ, Gias C, McDermott CJ, Lundh P, Pickering MC, Sethi C, Bird A, Fitzke FW, Maass A, Chen LL, Holder GE, Luthert PJ, Salt TE, Moss SE, Greenwood J (2007) Complement factor H deficiency in aged mice causes retinal abnormalities and visual dysfunction. Proc Natl Acad Sci U S A 104:16651-16656

14. Klein RJ, Zeiss C, Chew EY, Tsai JY, Sackler RS, Haynes C, Henning AK, SanGiovanni JP, Mane SM, Mayne ST, Bracken MB, Ferris FL, Ott J, Barnstable C, Hoh J (2005) Complement factor $\mathrm{H}$ polymorphism in age-related macular degeneration. Science 308:385-389

15. Rodriguez de Cordoba S, Esparza-Gordillo J, Goicoechea de Jorge E, Lopez-Trascasa M, Sanchez-Corral P (2004) The human complement factor $\mathrm{H}$ : functional roles, genetic variations and disease associations. Mol Immunol 41:355-367

16. Martin M, Blom AM (2016) Complement in removal of the deadbalancing inflammation. Immunol Rev 274:218-232

17. Stephan AH, Barres BA, Stevens B (2012) The complement system: an unexpected role in synaptic pruning during development and disease. Annu Rev Neurosci 35:369-389

18. Kolev M, Kemper C (2017) Keeping it all going-complement meets metabolism. Front Immunol 8:1

19. Lifson N, Kramlinger KG, Mayrand RR, Lender EJ (1980) Blood flow to the rabbit pancreas with special reference to the islets of Langerhans. Gastroenterology 79:466-473

20. Dimitriadis G, Mitrou P, Lambadiari V, Maratou E, Raptis SA (2011) Insulin effects in muscle and adipose tissue. Diabetes Res Clin Pract 93(Suppl 1):S52-S59

21. Baxter AG, Cooke A (1993) Complement lytic activity has no role in the pathogenesis of autoimmune diabetes in NOD mice. Diabetes 42:1574-1578

22. Conroy SJ, Abdel-Wahab YH, Caraher EM, Byrne PM, Murphy E, Nolan J, Flatt PR, Newsholme P (2000) Evidence for complement-dependent and -independent inhibition of insulin secretion from clonal beta-cells incubated in the presence of sera of newly diagnosed IDDM patients. J Endocrinol 164:139-147

23. Radillo O, Nocera A, Leprini A, Barocci S, Mollnes TE, Pocecco M, Pausa M, Valente U, Betterle C, Tedesco F (1996) Complement-fixing islet cell antibodies in type-1 diabetes can trigger the assembly of the terminal complement complex on human islet cells and are potentially cytotoxic. Clin Immunol Immunopathol 79:217-223

24. Lin M, Yin N, Murphy B, Medof ME, Segerer S, Heeger PS, Schroppel B (2010) Immune cell-derived c3 is required for autoimmune diabetes induced by multiple low doses of streptozotocin. Diabetes 59:2247-2252

25. Liszewski MK, Kolev M, Le Friec G, Leung M, Bertram PG, Fara AF, Subias M, Pickering MC, Drouet C, Meri S, Arstila TP, Pekkarinen PT, Ma M, Cope A, Reinheckel T, Rodriguez de Cordoba S, Afzali B, Atkinson JP, Kemper C (2013) Intracellular complement activation sustains $\mathrm{T}$ cell homeostasis and mediates effector differentiation. Immunity 39:1143-1157

26. Ahlqvist E, Storm P, Karajamaki A, Martinell M, Dorkhan M, Carlsson A, Vikman P, Prasad RB, Aly DM, Almgren P, Wessman Y, Shaat N, Spegel P, Mulder H, Lindholm E, Melander O, Hansson O, Malmqvist U, Lernmark A, Lahti K, Forsen T, Tuomi T, Rosengren AH, Groop L (2018) Novel subgroups of adult-onset diabetes and their association with outcomes: a data-driven cluster analysis of six variables. Lancet Diabetes Endocrinol 6:361-369 
27. Zou X, Zhou X, Zhu Z, Ji L (2019) Novel subgroups of patients with adult-onset diabetes in Chinese and US populations. Lancet Diabetes Endocrinol 7:9-11

28. Dennis JM, Shields BM, Henley WE, Jones AG, Hattersley AT (2019) Disease progression and treatment response in data-driven subgroups of type 2 diabetes compared with models based on simple clinical features: an analysis using clinical trial data. Lancet Diabetes Endocrinol 7:442-451

29. Ahlqvist E, Prasad RB, Groop L (2020) Subtypes of type 2 diabetes determined from clinical parameters. Diabetes 69:20862093

30. Gerl VB, Bohl J, Pitz S, Stoffelns B, Pfeiffer N, Bhakdi S (2002) Extensive deposits of complement $\mathrm{C} 3 \mathrm{~d}$ and $\mathrm{C} 5 \mathrm{~b}-9$ in the choriocapillaris of eyes of patients with diabetic retinopathy. Invest Ophthalmol Vis Sci 43:1104-1108

31. Flyvbjerg A (2017) The role of the complement system in diabetic nephropathy. Nat Rev Nephrol 13:311-318

32. Bus P, Chua JS, Klessens CQF, Zandbergen M, Wolterbeek R, van Kooten C, Trouw LA, Bruijn JA, Baelde HJ (2018) Complement activation in patients with diabetic nephropathy. Kidney Int Rep 3:302-313

33. Acosta J, Hettinga J, Fluckiger R, Krumrei N, Goldfine A, Angarita L, Halperin J (2000) Molecular basis for a link between complement and the vascular complications of diabetes. Proc Natl Acad Sci U S A 97:5450-5455

34. Ghosh P, Luque-Fernandez MA, Vaidya A, Ma D, Sahoo R, Chorev M, Zera C, McElrath TF, Williams MA, Seely EW, Halperin JA (2017) Plasma glycated CD59, a novel biomarker for detection of pregnancy-induced glucose intolerance. Diabetes Care 40:981-984

35. Qin X, Goldfine A, Krumrei N, Grubissich L, Acosta J, Chorev M, Hays AP, Halperin JA (2004) Glycation inactivation of the complement regulatory protein CD59: a possible role in the pathogenesis of the vascular complications of human diabetes. Diabetes 53: 2653-2661

36. Tabib A, Karbian N, Mevorach D (2017) Demyelination, strokes, and eculizumab: lessons from the congenital CD59 gene mutations. Mol Immunol 89:69-72

37. Valoti E, Noris M, Perna A, Rurali E, Gherardi G, Breno M, Parvanova Ilieva A, Petrov Iliev I, Bossi A, Trevisan R, Dodesini AR, Ferrari S, Stucchi N, Benigni A, Remuzzi G, Ruggenenti $\mathrm{P}$ (2019) Impact of a complement factor $\mathrm{H}$ gene variant on renal dysfunction, cardiovascular events, and response to ACE inhibitor therapy in type 2 diabetes. Front Genet 10:681

38. Greenfield JR, Campbell LV (2006) Relationship between inflammation, insulin resistance and type 2 diabetes: 'cause or effect'? Curr Diabetes Rev 2:195-211

39. Herder C, Illig T, Rathmann W, Martin S, Haastert B, MullerScholze S, Holle R, Thorand B, Koenig W, Wichmann HE, Kolb H, Group KS (2005) Inflammation and type 2 diabetes: results from KORA Augsburg. Gesundheitswesen 67(Suppl 1): S115-S121

40. Wlazlo N, van Greevenbroek MM, Ferreira I, Jansen EJ, Feskens EJ, van der Kallen CJ, Schalkwijk CG, Bravenboer B, Stehouwer CD (2012) Low-grade inflammation and insulin resistance independently explain substantial parts of the association between body fat and serum C3: the CODAM study. Metabolism 61: $1787-1796$

41. Engstrom G, Hedblad B, Eriksson KF, Janzon L, Lindgarde F (2005) Complement C3 is a risk factor for the development of diabetes: a population-based cohort study. Diabetes 54:570-575

42. Wlazlo N, van Greevenbroek MM, Ferreira I, Feskens EJ, van der Kallen CJ, Schalkwijk CG, Bravenboer B, Stehouwer CD (2014) Complement factor 3 is associated with insulin resistance and with incident type 2 diabetes over a 7-year follow-up period: the CODAM study. Diabetes Care 37:1900-1909
43. Weisberg SP, McCann D, Desai M, Rosenbaum M, Leibel RL, Ferrante AW Jr (2003) Obesity is associated with macrophage accumulation in adipose tissue. J Clin Invest 112:1796-1808

44. Feuerer M, Herrero L, Cipolletta D, Naaz A, Wong J, Nayer A, Lee J, Goldfine AB, Benoist C, Shoelson S, Mathis D (2009) Lean, but not obese, fat is enriched for a unique population of regulatory $\mathrm{T}$ cells that affect metabolic parameters. Nat Med 15: 930-939

45. Lumeng CN, Bodzin JL, Saltiel AR (2007) Obesity induces a phenotypic switch in adipose tissue macrophage polarization. J Clin Invest 117:175-184

46. Lumeng CN, Deyoung SM, Bodzin JL, Saltiel AR (2007) Increased inflammatory properties of adipose tissue macrophages recruited during diet-induced obesity. Diabetes 56:16-23

47. Rosen ED, Spiegelman BM (2014) What we talk about when we talk about fat. Cell 156:20-44

48. Tilg H, Moschen AR (2006) Adipocytokines: mediators linking adipose tissue, inflammation and immunity. Nat Rev Immunol 6: 772-783

49. Festa A, D'Agostino R Jr, Howard G, Mykkanen L, Tracy RP, Haffner SM (2000) Chronic subclinical inflammation as part of the insulin resistance syndrome: the Insulin Resistance Atherosclerosis Study (IRAS). Circulation 102:42-47

50. Rosen BS, Cook KS, Yaglom J, Groves DL, Volanakis JE, Damm D, White T, Spiegelman BM (1989) Adipsin and complement factor D activity: an immune-related defect in obesity. Science 244:1483-1487

51. Wu X, Hutson I, Akk AM, Mascharak S, Pham CTN, Hourcade DE, Brown R, Atkinson JP, Harris CA (2018) Contribution of adipose-derived factor $\mathrm{D} /$ adipsin to complement alternative pathway activation: lessons from lipodystrophy. J Immunol 200:27862797

52. Dobo J, Szakacs D, Oroszlan G, Kortvely E, Kiss B, Boros E, Szasz R, Zavodszky P, Gal P, Pal G (2016) MASP-3 is the exclusive pro-factor $\mathrm{D}$ activator in resting blood: the lectin and the alternative complement pathways are fundamentally linked. Sci Rep 6:31877

53. Takahashi M, Ishida Y, Iwaki D, Kanno K, Suzuki T, Endo Y, Homma Y, Fujita T (2010) Essential role of mannose-binding lectin-associated serine protease-1 in activation of the complement factor D. J Exp Med 207:29-37

54. Takahashi M, Iwaki D, Endo Y, Fujita T (2012) The study of MASPs knockout mice. In: Abdelmohsen K (ed) Binding Protein, pp 165-180

55. Baldo A, Sniderman AD, St-Luce S, Avramoglu RK, Maslowska M, Hoang B, Monge JC, Bell A, Mulay S, Cianflone K (1993) The adipsin-acylation stimulating protein system and regulation of intracellular triglyceride synthesis. J Clin Invest 92:1543-1547

56. Murray I, Havel PJ, Sniderman AD, Cianflone K (2000) Reduced body weight, adipose tissue, and leptin levels despite increased energy intake in female mice lacking acylation-stimulating protein. Endocrinology 141:1041-1049

57. Kalant D, Cain SA, Maslowska M, Sniderman AD, Cianflone K, Monk PN (2003) The chemoattractant receptor-like protein C5L2 binds the $\mathrm{C} 3 \mathrm{a}$ des-Arg77/acylation-stimulating protein. J Biol Chem 278:11123-11129

58. Johswich K, Martin M, Thalmann J, Rheinheimer C, Monk PN, Klos A (2006) Ligand specificity of the anaphylatoxin C5L2 receptor and its regulation on myeloid and epithelial cell lines. J Biol Chem 281:39088-39095

59. Li R, Coulthard LG, Wu MC, Taylor SM, Woodruff TM (2013) C5L2: a controversial receptor of complement anaphylatoxin, C5a. FASEB J 27:855-864

60. Wetsel RA, Kildsgaard J, Zsigmond E, Liao W, Chan L (1999) Genetic deficiency of acylation stimulating protein (ASP(C3ades- 
Arg)) does not cause hyperapobetalipoproteinemia in mice. J Biol Chem 274:19429-19433

61. Cianflone K, Xia Z, Chen LY (2003) Critical review of acylationstimulating protein physiology in humans and rodents. Biochim Biophys Acta 1609:127-143

62. Fontaine DA, Davis DB (2016) Attention to background strain is essential for metabolic research: $\mathrm{C} 57 \mathrm{BL} / 6$ and the International Knockout Mouse Consortium. Diabetes 65:25-33

63. Lim J, Iyer A, Suen JY, Seow V, Reid RC, Brown L, Fairlie DP (2013) C5aR and C3aR antagonists each inhibit diet-induced obesity, metabolic dysfunction, and adipocyte and macrophage signaling. FASEB J 27:822-831

64. Cianflone K, Maslowska M (1995) Differentiation-induced production of ASP in human adipocytes. Eur J Clin Investig 25:817825

65. Mamane Y, Chung Chan C, Lavallee G, Morin N, Xu LJ, Huang J, Gordon R, Thomas W, Lamb J, Schadt EE, Kennedy BP, Mancini JA (2009) The C3a anaphylatoxin receptor is a key mediator of insulin resistance and functions by modulating adipose tissue macrophage infiltration and activation. Diabetes 58:20062017

66. Choy LN, Rosen BS, Spiegelman BM (1992) Adipsin and an endogenous pathway of complement from adipose cells. J Biol Chem 267:12736-12741

67. Phieler J, Chung KJ, Chatzigeorgiou A, Klotzsche-von Ameln A, Garcia-Martin R, Sprott D, Moisidou M, Tzanavari T, Ludwig B, Baraban E, Ehrhart-Bornstein M, Bornstein SR, Mziaut H, Solimena M, Karalis KP, Economopoulou M, Lambris JD, Chavakis T (2013) The complement anaphylatoxin C5a receptor contributes to obese adipose tissue inflammation and insulin resistance. J Immunol 191:4367-4374

68. Scott RA, Scott LJ, Magi R, Marullo L, Gaulton KJ et al (2017) An expanded genome-wide association study of type 2 diabetes in Europeans. Diabetes 66:2888-2902

69. Hotamisligil GS, Shargill NS, Spiegelman BM (1993) Adipose expression of tumor necrosis factor-alpha: direct role in obesitylinked insulin resistance. Science 259:87-91

70. Gomez-Banoy N, Guseh JS, Li G, Rubio-Navarro A, Chen T, Poirier B, Putzel G, Rosselot C, Pabon MA, Camporez JP, Bhambhani V, Hwang SJ, Yao C, Perry RJ, Mukherjee S, Larson MG, Levy D, Dow LE, Shulman GI, Dephoure N, Garcia-Ocana A, Hao M, Spiegelman BM, Ho JE, Lo JC (2019) Adipsin preserves beta cells in diabetic mice and associates with protection from type 2 diabetes in humans. Nat Med 25:17391747

71. Lee MJ, Wu Y, Fried SK (2013) Adipose tissue heterogeneity: implication of depot differences in adipose tissue for obesity complications. Mol Asp Med 34:1-11

72. Tran TT, Kahn CR (2010) Transplantation of adipose tissue and stem cells: role in metabolism and disease. Nat Rev Endocrinol 6: 195-213

73. Flier JS, Cook KS, Usher P, Spiegelman BM (1987) Severely impaired adipsin expression in genetic and acquired obesity. Science 237:405-408

74. Platt KA, Min HY, Ross SR, Spiegelman BM (1989) Obesitylinked regulation of the adipsin gene promoter in transgenic mice. Proc Natl Acad Sci U S A 86:7490-7494

75. Lo JC, Ljubicic S, Leibiger B, Kern M, Leibiger IB, Moede T, Kelly ME, Chatterjee Bhowmick D, Murano I, Cohen P, Banks AS, Khandekar MJ, Dietrich A, Flier JS, Cinti S, Bluher M, Danial NN, Berggren PO, Spiegelman BM (2014) Adipsin is an adipokine that improves beta cell function in diabetes. Cell 158: $41-53$

76. Volanakis JE, Barnum SR, Giddens M, Galla JH (1985) Renal filtration and catabolism of complement protein D. N Engl J Med 312:395-399
77. Misra A, Peethambaram A, Garg A (2004) Clinical features and metabolic and autoimmune derangements in acquired partial lipodystrophy: report of 35 cases and review of the literature. Medicine (Baltimore) 83:18-34

78. Peters DK, Charlesworth JA, Sissons JG, Williams DG, BoultonJones JM, Evans DJ, Kourilsky O, Morel-Maroger L (1973) Mesangiocapillary nephritis, partial lipodystrophy, and hypocomplementaemia. Lancet 2:535-538

79. Mathieson PW, Wurzner R, Oliveria DB, Lachmann PJ, Peters DK (1993) Complement-mediated adipocyte lysis by nephritic factor sera. J Exp Med 177:1827-1831

80. Kahn BB (1998) Type 2 diabetes: when insulin secretion fails to compensate for insulin resistance. Cell 92:593-596

81. Donath MY, Boni-Schnetzler M, Ellingsgaard H, Ehses JA (2009) Islet inflammation impairs the pancreatic beta-cell in type 2 diabetes. Physiology (Bethesda) 24:325-331

82. Ehses JA, Perren A, Eppler E, Ribaux P, Pospisilik JA, MaorCahn R, Gueripel X, Ellingsgaard H, Schneider MK, Biollaz G, Fontana A, Reinecke M, Homo-Delarche F, Donath MY (2007) Increased number of islet-associated macrophages in type 2 diabetes. Diabetes 56:2356-2370

83. Kemper C, Chan AC, Green JM, Brett KA, Murphy KM, Atkinson JP (2003) Activation of human CD4+ cells with CD3 and CD46 induces a T-regulatory cell 1 phenotype. Nature 421: 388-392

84. Kolev M, Dimeloe S, Le Friec G, Navarini A, Arbore G, Povoleri GA, Fischer M, Belle R, Loeliger J, Develioglu L, Bantug GR, Watson J, Couzi L, Afzali B, Lavender P, Hess C, Kemper C (2015) Complement regulates nutrient influx and metabolic reprogramming during Th1 Cell responses. Immunity 42:10331047

85. King BC, Esguerra JL, Golec E, Eliasson L, Kemper C, Blom AM (2016) CD46 activation regulates miR-150-mediated control of GLUT1 expression and cytokine secretion in human CD4+ T cells. J Immunol 196:1636-1645

86. Krus U, King BC, Nagaraj V, Gandasi NR, Sjolander J, Buda P, Garcia-Vaz E, Gomez MF, Ottosson-Laakso E, Storm P, Fex M, Vikman P, Zhang E, Barg S, Blom AM, Renstrom E (2014) The complement inhibitor CD59 regulates insulin secretion by modulating exocytotic events. Cell Metab 19:883-890

87. King BC, Kulak K, Krus U, Rosberg R, Golec E, Wozniak K, Gomez MF, Zhang E, O'Connell DJ, Renstrom E, Blom AM (2019) Complement component $\mathrm{C} 3$ is highly expressed in human pancreatic islets and prevents beta cell death via ATG16L1 interaction and autophagy regulation. Cell Metab 29(202-10):e6

88. Sorbara MT, Foerster EG, Tsalikis J, Abdel-Nour M, Mangiapane J, Sirluck-Schroeder I, Tattoli I, van Dalen R, Isenman DE, Rohde JR, Girardin SE, Philpott DJ (2018) Complement C3 drives autophagy-dependent restriction of cyto-invasive bacteria. Cell Host Microbe 23(644-52):e5

89. King BC, Kulak K, Colineau L, Blom AM (2020) Outside in: roles of complement in autophagy. Br J Pharmacol

90. King BC, Renstrom E, Blom AM (2019) Intracellular cytosolic complement component $\mathrm{C} 3$ regulates cytoprotective autophagy in pancreatic beta cells by interaction with ATG16L1. Autophagy 15:919-921

91. Dos Santos RS, Marroqui L, Grieco FA, Marselli L, Suleiman M, Henz SR, Marchetti P, Wernersson R, Eizirik DL (2017) Protective role of complement $\mathrm{C} 3$ against cytokine-mediated beta-cell apoptosis. Endocrinology 158:2503-2521

92. Kulkarni HS, Elvington ML, Perng YC, Liszewski MK, Byers DE, Farkouh C, Yusen RD, Lenschow DJ, Brody SL, Atkinson JP (2019) Intracellular C3 protects human airway epithelial cells from stress-associated cell death. Am J Respir Cell Mol Biol 60: 144-157 
93. Brodsky RA (2014) Paroxysmal nocturnal hemoglobinuria. Blood 124:2804-2811

94. Golec E, Rosberg R, Zhang E, Renstrom E, Blom AM, King BC (2019) A cryptic non-GPI-anchored cytosolic isoform of CD59 controls insulin exocytosis in pancreatic beta-cells by interaction with SNARE proteins. FASEB J 33:12425-12434

95. Nagaraj V, King B, Storm P, Vikman P, Ottosson-Laakso E, Blom AM, Renstrom E (2015) Complement inhibitor CD55 governs the integrity of membrane rafts in pancreatic beta cells, but plays no role in insulin secretion. Biochem Biophys Res Commun 460: $518-524$

96. Qian YM, Qin X, Miwa T, Sun X, Halperin JA, Song WC (2000) Identification and functional characterization of a new gene encoding the mouse terminal complement inhibitor CD59. J Immunol 165:2528-2534

97. Boshra H, Zelek WM, Hughes TR, Rodriguez de Cordoba S, Morgan BP (2018) Absence of CD59 in guinea pigs: analysis of the cavia porcellus genome suggests the evolution of a CD59 pseudogene. J Immunol 200:327-335

98. Westermark P, Andersson A, Westermark GT (2011) Islet amyloid polypeptide, islet amyloid, and diabetes mellitus. Physiol Rev 91:795-826

99. Sjoberg AP, Nystrom S, Hammarstrom P, Blom AM (2008) Native, amyloid fibrils and beta-oligomers of the C-terminal domain of human prion protein display differential activation of complement and bind $\mathrm{C} 1 \mathrm{q}$, factor $\mathrm{H}$ and $\mathrm{C} 4 \mathrm{~b}$-binding protein directly. Mol Immunol 45:3213-3221

100. Sjolander J, Westermark GT, Renstrom E, Blom AM (2012) Islet amyloid polypeptide triggers limited complement activation and binds complement inhibitor $\mathrm{C} 4 \mathrm{~b}$-binding protein, which enhances fibril formation. J Biol Chem 287:10824-10833

101. Raleigh D, Zhang X, Hastoy B, Clark A (2017) The beta-cell assassin: IAPP cytotoxicity. J Mol Endocrinol 59:R121-RR40
102. Sjolander J, Byman E, Kulak K, Nilsson SC, Zhang E, Krus U, Westermark GT, Storm P, King BC, Renstrom E, Blom AM (2016) C4b-binding protein protects beta-cells from islet amyloid polypeptide-induced cytotoxicity. J Biol Chem 291:21644-21655

103. Masters SL, Dunne A, Subramanian SL, Hull RL, Tannahill GM, Sharp FA, Becker C, Franchi L, Yoshihara E, Chen Z, Mullooly N, Mielke LA, Harris J, Coll RC, Mills KH, Mok KH, Newsholme P, Nunez G, Yodoi J, Kahn SE, Lavelle EC, O’Neill LA (2010) Activation of the NLRP3 inflammasome by islet amyloid polypeptide provides a mechanism for enhanced IL-1beta in type 2 diabetes. Nat Immunol 11:897-904

104. Dinarello CA, Donath MY, Mandrup-Poulsen T (2010) Role of IL-1beta in type 2 diabetes. Curr Opin Endocrinol Diabetes Obes 17:314-321

105. Kulak K, Westermark GT, Papac-Milicevic N, Renstrom E, Blom AM, King BC (2017) The human serum protein C4b-binding protein inhibits pancreatic IAPP-induced inflammasome activation. Diabetologia 60:1522-1533

106. King BC, Blom AM (2017) Non-traditional roles of complement in type 2 diabetes: metabolism, insulin secretion and homeostasis. Mol Immunol 84:34-42

107. Shokal U, Kopydlowski H, Harsh S, Eleftherianos I (2018) Thioester-containing proteins 2 and 4 affect the metabolic activity and inflammation response in drosophila. Infect Immun 86

108. Donath MY (2014) Targeting inflammation in the treatment of type 2 diabetes: time to start. Nat Rev Drug Discov 13:465-476

109. Harris CL, Pouw RB, Kavanagh D, Sun R, Ricklin D (2018) Developments in anti-complement therapy: from disease to clinical trial. Mol Immunol 102:89-119

Publisher's note Springer Nature remains neutral with regard to jurisdictional claims in published maps and institutional affiliations. 